\title{
ZWACKHIOMYCES POLISCHUKII SP. NOV., AND OTHER NOTEWORTHY LICHENICOLOUS FUNGI FROM UKRAINE
}

\author{
Alexander Ye. Khodosovtsev ${ }^{1}$ \& VAleriy V. Darmostuk
}

\begin{abstract}
The new lichenicolous fungus Zwackhiomyces polischukii Darmostuk \& Khodos. is described from Bacidia fraxinea Lönnr. and B. rubella (Hoffm.) A. Massal. in Ukraine. Cercidospora caudata Kernst., Cladophialophora parmeliae (Etayo \& Diederich) Diederich \& Untereiner, Epicladonia simplex D. Hawksw., Laetisaria lichenicola Diederich, Lawrey \& Van den Broeck, Lichenochora caloplacae Zhurb., L. weillii (Werner) Hafellner \& R. Sant., Microsphaeropsis caloplacae Etayo $\&$ Yazıc1, Pronectria casaresii Etayo and $P$. cf. dillmaniae Zhurb. are new for Ukraine. Seven species are new for the plains of Ukraine and four species are new for the steppe zone. Pronectria diplococca, P. cf. dillmaniae, Lichenochora caloplacae and Microsphaeropsis caloplacae were previously known only from their original descriptions.
\end{abstract}

Key words: Cercidospora, Pronectria, Lichenochora, Zwackhiomyces, distribution, new species, steppe zone

Alexander Khodosovtsev \& Valeriy Darmostuk, Chair of Botany, Kherson State University, 27 Universytetska St., 73000 Kherson, Ukraine; e-mail: khodosovtsev@i.ua,valeriy_d@i.ua

\section{INTRODUCTION}

The lichenicolous fungi of Ukraine are still poorly known, although research on them has increased recently (e.g., Braun et al. 2016; Darmostuk 2016; Darmostuk \& Naumovich 2016; Kapets 2016; Khodosovtsev \& Darmostuk 2016; Khodosovtsev et al. 2016a, b). Last year we organized several excursions to forests in northern and southern Ukraine, to granitic canyons along small steppe rivers and to loess outcrops in the Dnieper-Bug estuary. Lichenicolous fungi recorded during our excursions and some older herbarium collections are presented in this paper.

\section{MATERIALS AND METHODS}

Specimens were examined using standard light microscopy techniques and LOMO microscopes (MBS-1, Micromed-2). Specimens were examined in water, $10 \% \mathrm{KOH}(\mathrm{K})$, Lugol's iodine, directly (I) or after $\mathrm{KOH}$ pretreatment $(\mathrm{K} / \mathrm{I})$ or with Brilliant Cresyl blue $(\mathrm{BCr})$. We measured specimens in water to $0.25 \mu \mathrm{m}$ accuracy for ascospores, asci, conidia, conidiogenous cells, conidiophores, and ascomatal and pycnidial wall cells, and to $5 \mu \mathrm{m}$ accuracy for ascomata, basidiomata and pycnidia. Measurements are given as (min-)meanSD-mean+SD(-max). Photographs were taken with a Levenhuk C510 NG camera. All examined specimens are deposited in the lichenological herbarium of Kherson State University (KHER).

\section{RESULTS AND DISCUSSION}

Briancoppinsia cytospora (Vouaux) Diederich, Ertz, Lawrey \& van den Boom

SPECIMENS EXAMINED (all on thalli of Parmelia sulcata s.1.). UKRAINE. KHERSON REGION. Oleshkivskiy district, near Burkuty village, $46^{\circ} 23^{\prime} 38.6^{\prime \prime} \mathrm{N}, 32^{\circ} 48^{\prime} 35.7^{\prime \prime} \mathrm{E}$, alt. $13 \mathrm{~m}$, on Quercus robur, 18 Nov. 2016, A. Khodosovtsev \& V. Darmostuk (KHER 10316). SUMY REGION. Seredyno-Budskiy district, Desniansko-Starogutskiy National Nature Park, Uborok, $52^{\circ} 15^{\prime} 12.7^{\prime \prime} \mathrm{N}, 33^{\circ} 35^{\prime} 5.2^{\prime \prime} \mathrm{E}$, alt. $130 \mathrm{~m}$, on Q. robur, 5 Aug. 2016, A. Khodosovtsev \& V. Darmostuk (KHER 10178).

Notes. This lichenicolous fungus was recently reported from the Carpathian Mts (Kondratyuk et al. 2003). New for the plains of Ukraine.

\footnotetext{
1 Corresponding author
} 


\section{Cercidospora caudata Kernst. s.l.}

Specimens examined. UKRAINE. Autonomous Republic of Crimea. Cape Plaka, $44^{\circ} 35^{\prime} 30.7^{\prime \prime} \mathrm{N}$, $34^{\circ} 22^{\prime} 12.9^{\prime \prime} \mathrm{E}$, alt. $90 \mathrm{~m}$, on thalli of Olegblumia demissa, on porphyrite outcrops, 13 Nov. 1999, A. Khodosovtsev \& O. Redchenko (KHER 10323).

Notes. Our specimen has immersed ascomata (145-)150-170(-185) $\mu \mathrm{m}$ diam., a blue-green peridial wall around the ostiole, (6-)8-spored asci, and colorless, 1-septate, heteropolar ascospores $(16.5-) 17.0-18.5(-20.0) \times(4.0-) 4.5-6.0(-6.3) \mu \mathrm{m}$. These characters fit the concept of Cercidospora caudata s.l. (Navarro-Rosinés et al. 2004). The taxonomy of this group is in need of a thorough revision. Cercidospora caudata s.l. is known from Europe: Austria (Hafellner 1987), Germany (Brackel 2007), Italy (Kernstock 1896), Spain (Etayo \& Pérez-Ortega 2016), Switzerland (Groner 2009); Asia: India (Joshi et al. 2016), South Korea (Joshi et al. 2015), Turkey (Halici et al. 2007); Africa: Morocco (Brackel 2014); North America: USA (Triebel et al. 1991); South America: Guatemala (Etayo \& van den Boom 2006). Originally Cercidospora caudata was described on Xanthocarpia lactea (A. Massal.) A. Massal. but our specimen was collected on Olegblumia demissa (Flot.) S. Y. Kondr., L. Lőkös, J. Kim, A. S. Kondr., S. O. Oh \& J. S. Hur.

Cercidospora xanthoriae (Wedd.) R. Sant. s.1.

Specimens examined. UKRAINE. Mykolayiv REGION. Voznesenskiy district, near Trykraty village, Buzky Gard National Nature Park, Arbuzinskiy Canyon, $47^{\circ} 42^{\prime} 24.9^{\prime \prime} \mathrm{N}, 31^{\circ} 25^{\prime} 56.9^{\prime \prime} \mathrm{E}$, alt. $42 \mathrm{~m}$, on apothecia of Rufoplaca subpallida, on granite outcrops, 20 Oct. 2016, A. Khodosovtsev \& V. Darmostuk (KHER 10320).

Notes. In contrast to Cercidospora caudata s.l., this species has more or less unequal ascospore cells. Although previously known from Ukraine from the Crimean peninsula (Kondratyuk et al. 1999; Darmostuk 2016), it is new for the plains of Ukraine.

Cladophialophora parmeliae (Etayo \& Diederich) Diederich \& Untereiner

Specimen examined. UKRAINE. Mykolayiv REGION. Voznesenskiy district, near Trykraty village,
Buzky Gard National Nature Park, Arbuzinskiy Canyon, $47^{\circ} 42^{\prime} 24.9^{\prime \prime} \mathrm{N}, 31^{\circ} 25^{\prime} 56.9^{\prime \prime} \mathrm{E}$, alt. $42 \mathrm{~m}$, on thalli of Xanthoparmelia conspersa which was also infected by Lichenoconium erodens, on granite outcrops, 20 Oct. 2016, A. Khodosovtsev \& V. Darmostuk (KHER 10312).

Notes. The species is characterized by sporodochia-like conidiomata and slightly to distinctly verrucose, ellipsoid 1-septate brownish conidia (Diederich et al. 2013). It is known from Europe: Austria, the Azores, France, United Kingdom (Etayo \& Diederich 1996; Diederich et al. 2013); Asia (Zhurbenko et al. 2015). New for Ukraine.

\section{Clypeococcum cetrariae Hafellner}

SPeCimens EXAmined. UKRAINE. Mykolayiv REGION. Ochakovskiy district, near Pokrovka village, Kinburnska Kosa Regional Landscape Park, 46 $28^{\prime} 48.4^{\prime \prime} \mathrm{N}$, $31^{\circ} 39^{\prime} 55.9^{\prime \prime} \mathrm{E}$, alt. $2 \mathrm{~m}$, on thalli of Cetraria aculeata above sand dunes, 18 July 2016, V. Darmostuk (KHER 10134). Sumy REGION. Seredyno-Budskiy district, Desniansko Starogutsky National Nature Park, near Ulytsa village, $52^{\circ} 18^{\prime} 39.6^{\prime \prime} \mathrm{N}, 33^{\circ} 36^{\prime} 57.4^{\prime \prime} \mathrm{E}$, alt. $132 \mathrm{~m}$, on thalli of Cetraria islandica, 5 Aug. 2016, A. Khodosovtsev \& V. Darmostuk (KHER 10182, 10184, 10187).

Notes. In Ukraine the species was collected in the Carpathian Mts (Pirogov 2015). New for the plains of Ukraine.

Clypeococcum hypocenomycis D. Hawksw.

SPECIMEN EXAmined. UKRAINE. Kherson ReGION. Oleshkivskiy district, near Radensk village, $46^{\circ} 33^{\prime} 57.1^{\prime \prime} \mathrm{N}, 32^{\circ} 52^{\prime} 40.2^{\prime \prime} \mathrm{E}$, alt., $32 \mathrm{~m}$, on thalli of Hypocenomyce scalaris, on Pinus nigra, 20 Nov. 2016, V. Darmostuk (KHER 10317).

Notes. Although this species was recently found in the Lviv region (Pirogov 2010), it is new for the steppe zone of Ukraine.

Epicladonia simplex D. Hawksw.

SPECIMEN EXAMINED. UKRAINE. KHeRson REGION. Oleshkivskiy district, Sagi Landscape Reserve, $46^{\circ} 37^{\prime} 04.03^{\prime \prime} \mathrm{N}, 32^{\circ} 50^{\prime} 03.13^{\prime \prime} \mathrm{E}$, alt. $15 \mathrm{~m}$, on Cladonia rangiformis, on sand dunes, 4 Oct. 2016, G. Naumovich (KHER 10156).

Notes. This is a widespread lichenicolous fungus known from Europe: Denmark (Alstrup 1994), Finland (Hawksworth 1981), Iceland 
(Heiđmarsson et al. 2009), Lithuania (Motiejūnaite 2011), Poland (Kukwa et al. 2013), Sweden (Ihlen \& Wedin 2006); Asia: Russia (Zhurbenko 2004), South Korea (Joshi et al. 2015); North America: Canada (Alstrup \& Cole 1998), USA (Esslinger \& Egan 1995). New for Ukraine.

\section{Heterocephalacria bachmannii (Diederich}

\& M. S. Christ.) Millanes \& Wedin

SPECIMEN EXAmined. UKRAINE. Kherson ReGION. Oleshkivskiy district, near Radensk village, $46^{\circ} 33^{\prime} 57.1^{\prime \prime} \mathrm{N}, 32^{\circ} 52^{\prime} 40.2^{\prime \prime} \mathrm{E}$, alt., $32 \mathrm{~m}$, on Cladonia rangiformis, on sand dunes, 20 Nov. 2016, V. Darmostuk (KHER 10324).

Notes. This lichenicolous fungus was recently reported from the Crimean peninsula (Khodosovtsev 2013). New for the plains of Ukraine.

Illosporiopsis christiansenii (B. L. Brady

\& D. Hawksw.) D. Hawksw.

Specimens eXAmined (all on thalli of Physcia adscendens). UKRAINE. KHERSON REGION. Velykooleksandrivkiy district, Mala Oleksandrivka village, Rusova balka, $47^{\circ} 16^{\prime} 15.93^{\prime \prime} \mathrm{N}, 33^{\circ} 14^{\prime} 05.43^{\prime \prime} \mathrm{E}$, alt. 37 m, on Quercus robur, 9 Jan. 2016, V. Darmostuk (KHER 9652); Oleshkivskiy district, near Burkuty village, $46^{\circ} 23^{\prime} 38.6^{\prime \prime} \mathrm{N}, 32^{\circ} 48^{\prime} 35.7^{\prime \prime} \mathrm{E}$, alt. $13 \mathrm{~m}$, on Q. robur, 21 Nov. 2015, A. Khodosovtsev \& V. Darmostuk (KHER 9550, 9574). MyKolayiv REGION. Voznesenskiy district, near Trykraty village, Buzky Gard National Nature Park, Labirynt, $47^{\circ} 42^{\prime} 24.9^{\prime \prime} \mathrm{N}$, $31^{\circ} 25^{\prime} 56,9^{\prime \prime} \mathrm{E}$, alt. $42 \mathrm{~m}$, on Fraxinus excelsior, 21 Oct. 2016, A. Khodosovtsev \& V. Darmostuk (KHER 10319). Sumy REgion. Seredyno-Budskiy district, DesnianskoStarogutsky National Nature Park, near Ochkino village, $52^{\circ} 15^{\prime} 44.1^{\prime \prime} \mathrm{N}, 33^{\circ} 23^{\prime} 21.4^{\prime \prime} \mathrm{E}$, alt. $131 \mathrm{~m}$, on Salix sp., 1 Aug. 2016, A. Khodosovtsev \& V. Darmostuk (KHER 10325).

Notes. Previously known only from the Carpathian Mts (Hawksworth 1992). New for the plains of Ukraine.

Laetisaria lichenicola Diederich, Lawrey \& Van den Broeck

SPECIMENS EXAMined (all on Physcia adscendens). UKRAINE. KHERSON REGION. Belozerskiy district, Sofievka village, Sofiyevska Balka Botanical Reserve, $46^{\circ} 36^{\prime} 03.93^{\prime \prime} \mathrm{N}, 32^{\circ} 15^{\prime} 41.13^{\prime \prime} \mathrm{E}$, alt. $13 \mathrm{~m}$, on Robinia pseudoacacia, 14 Dec. 2016, A. Khodosovtsev \& V. Darmostuk (KHER 10318); Velykooleksandrivkiy district, Mala Oleksandrivka village, right bank of river Ingulets, $47^{\circ} 17^{\prime} 38.47^{\prime \prime} \mathrm{N}, 33^{\circ} 16^{\prime} 24.21^{\prime \prime} \mathrm{E}$, alt. $21 \mathrm{~m}$, on Populus nigra, 27 Nov. 2016, V. Darmostuk (KHER 10313).

Notes. Laetisaria lichenicola grows on Physcia together with Erythricium aurantiacum (Lasch) D. Hawksw. \& A. Henrici, but the former differs in the rose color of infected thalli. This is the second member of the genus Laetiaria in Ukraine, the other being L. fuciformis (Akulov et al. 2010). It is known from Belgium, Germany and Luxembourg (Diederich et al. 2011). New for Eastern Europe.

\section{Lichenochora caloplacae Zhurb.}

SPeCimens eXAmined. UKRAINE. Kherson REGION. Belozerskiy district, Sofievska Balka Botanical Reserve, $46^{\circ} 36^{\prime} 03.93^{\prime \prime} \mathrm{N}, 32^{\circ} 15^{\prime} 41.13^{\prime \prime} \mathrm{E}$, alt. $13 \mathrm{~m}$, on thalli of Athallia skii, on plant debris, 14 Feb. 2009, A. Khodosovtsev \& L. Gavrylenko (KHER 7574); near Alexandrovka village, 46 36 $23.7^{\prime \prime} \mathrm{N}$, $32^{\circ} 15^{\prime} 54.3^{\prime \prime} \mathrm{E}$, alt. $17 \mathrm{~m}$, on thalli of $A$. skii, on plant debris, 14 Dec. 2016, A. Khodosovtsev \& V. Darmostuk (KHER 10326).

Notes. The specimens of Lichenochora caloplacae from Ukraine are mostly consistent with the protologue (Zhurbenko \& Brackel 2013), but differ slightly in having shorter ascospores $18-23 \times 3.0$ $4.5 \mu \mathrm{m}(14-27 \times 3.5-6.0$ in original description $)$ and in the host. This recently described species was known from polar desert biomes of Svalbard and Central Siberia (Zhurbenko \& Brackel 2013), growing on thalli of terricolous caloplacoid species. Athallia skii (Khodos., Vondrák \& Šoun) Arup, Frödén \& Søchting is a new host species and it is the first record of any lichenicolous fungus on this lichen. New for Ukraine.

Lichenochora weillii (Werner) Hafellner \& R. Sant.

SPECIMEN EXAmined. UKRAINE. KHerson ReGION. Oleshkivskiy district, near Burkuty village, $46^{\circ} 23^{\prime} 38.6^{\prime \prime} \mathrm{N}, 32^{\circ} 48^{\prime} 35.7^{\prime \prime} \mathrm{E}$, alt. $13 \mathrm{~m}$, on thalli of Physconia grisea, on Quercus robur, 18 Nov. 2016, A. Khodosovtsev \& V. Darmostuk (KHER 10311).

Notes. The species is known from Europe: Belgium (van den Boom \& Brand 2008), France 
(Diederich et al. 2012), Germany (Kocourková \& von Brackel 2005), Italy (van den Boom \& Brand 2008), Latvia (Motiejūnaite et al. 2016), Svalbard (Zhurbenko \& Brackel 2013), Spain (Werner 1937), Sweden (Hafellner 1989), the Netherlands (van den Boom \& Brand 2008); Asia: Russia (Zhurbenko \& Santesson 1996); North America: Canada (Hafellner 1989); Macaronesian islands (Hafellner 2002). New for Ukraine.

\section{Lichenostigma maureri Hafellner}

Specimens eXAmined. UKRAINE. Kherson ReGION. Oleshkivskiy district, near Burkuty village, $46^{\circ} 23^{\prime} 38.6^{\prime \prime} \mathrm{N}, 32^{\circ} 48^{\prime} 35.7^{\prime \prime} \mathrm{E}$, alt. $13 \mathrm{~m}$, on thalli of Pseudoevernia furfuracea, on Quercus robur, 21 Nov. 2015, A. Khodosovtsev \& V. Darmostuk (KHER 9548); SumY REGION. Seredyno-Budskiy district, DesnianskoStarogutsky National Nature Park, near Stara Guta village, $52^{\circ} 18^{\prime} 39.6^{\prime \prime} \mathrm{N}, 33^{\circ} 36^{\prime} 57.4^{\prime \prime} \mathrm{E}$, alt. $132 \mathrm{~m}$, on thalli of P. furfuracea, on Q. robur, 5 Aug. 2016, A. Khodosovtsev \& V. Darmostuk (KHER 10254).

Notes. In Ukraine this species was found on the Crimean peninsula and in the Carpathian Mts (Hawksworth 1992; Khodosovtsev et al. 2013, 2016c). New for the plains of Ukraine.

\section{Microsphaeropsis caloplacae Etayo \& Yazıcı}

SPECIMEN EXAMINED. UKRAINE. KHERSON REGION. Bilozerskiy district, near Alexandrovka village, $46^{\circ} 36^{\prime} 23.7^{\prime \prime} \mathrm{N}, 32^{\circ} 15^{\prime} 54.3^{\prime \prime} \mathrm{E}$, alt. $17 \mathrm{~m}$, on thalli of $\mathrm{Ca}$ logaya lobulata, on plant debris, 14 Dec. 2016, A. Khodosovtsev \& V. Darmostuk (KHER 10326).

Notes. This recently described species has small pycnidia $30-50 \mu \mathrm{m}$ diam. and hyaline to brown aseptate conidia $7.2-8.3 \times 4-6 \mu \mathrm{m}$. Our specimen has few pycnidia and differs by having slightly smaller conidia, $6.5-7.5 \times 3-5 \mu \mathrm{m}$. It was known only from the type locality in Turkey on Calogaya persica (J. Steiner) Arup, Frödén \& Søchting (Etayo \& Yazıcı 2009). Calogaya lobulata (Flörke) Arup, Frödén \& Søchting is a new host species. New for Ukraine.

\section{Nectriopsis rubefaciens (Ellis \& Everh.)}

M. S. Cole \& D. Hawksw.

Specimen examined. UKRAINE. Kherson ReGION. Oleshkivskiy district, near Burkuty village, $46^{\circ} 23^{\prime} 38.6^{\prime \prime} \mathrm{N}, 32^{\circ} 48^{\prime} 35.7^{\prime \prime} \mathrm{E}$, alt. $13 \mathrm{~m}$, on thalli of Parmelia sulcata above wood, 8 July 2015, A. Khodosovtsev (KHER 9269).

Notes. Although previously known from the Lviv region (Pirogov 2011), it is new for the steppe zone of Ukraine.

\section{Pronectria casaresii Etayo}

Specimen eXAmined. UKRAINE. Kherson ReGION. Oleshkivskiy district, near Burkuty village, $46^{\circ} 23^{\prime} 38.6^{\prime \prime} \mathrm{N}, 32^{\circ} 48^{\prime} 35.7^{\prime \prime} \mathrm{E}$, alt. $13 \mathrm{~m}$, on thalli of Evernia prunastri, on Prunus spinosa, 18 Nov. 2016, A. Khodosovtsev \& V. Darmostuk (KHER 10314).

Notes. This lichenicolous fungus was known from Spain (Etayo 1998; van den Boom \& Etayo 2014). New for Eastern Europe.

\section{Pronectria cf. dillmaniae Zhurb.}

SPECIMEN EXAMINED. UKRAINE. KHERSON REGION. Belozerskiy district, near Vysunci village, $46^{\circ} 43^{\prime} 23.8^{\prime \prime} \mathrm{N}$, $32^{\circ} 35^{\prime} 26.0^{\prime \prime} \mathrm{E}$, alt. $15 \mathrm{~m}$, on thalli of Placidium squamulosum above soil, 8 May 2016, I. Moysiyenko (KHER 10315).

Notes. The specimen is poorly developed, with three perithecia only, but we identified it as Pronectria cf. dillmaniae: ascospores 8.5-10.5 $\times$ 5.2-6.3 $\mu \mathrm{m}$ (vs 6-12 $\times 4-7 \mu \mathrm{m}$ in original description) and perithecia ca $120 \mu \mathrm{m}$ diam. (vs. 100-200 $\mu \mathrm{m}$ ). Our material was found on Placidium squamulosum (Ach.) Breuss, whereas the original host in the type locality in the USA is Catapyrenium cinereum (Pers.) Körb. (Zhurbenko et al. 2005). Pronectria dillmaniae is not known otherwise from Europe.

Pronectria diplococca Kocourk., Khodos., Naumovich, Vondrák \& Motiej.

SPeCimen EXAMINed. UKRAINE. PoltaVA REgion. Semenivsky district, near Obolon village, saline soil, on Enchylium tenax, 49 33'2"N, 3251'35.8'E, 3 May 2016, A. Khodosovtsev \& V. Darmostuk (KHER 9866).

Notes. A recently described species (Khodosovtsev et al. 2012) based on material from Ukraine, Lithuania and the Czech Republic. Here we provide a further locality in the forest-steppe zone of Ukraine. 
Stigmidium squamariae (B. de Lesd.) Cl. Roux \& Triebel

Specimen examined. UKRAINE. Mykolayiv REGION. Voznesenskiy district, near Trykraty village, Buzky Gard National Nature Park, Arbuzinskiy Canyon, $47^{\circ} 42^{\prime} 24.9^{\prime \prime} \mathrm{N}, 31^{\circ} 25^{\prime} 56.9^{\prime \prime} \mathrm{E}$, alt. $42 \mathrm{~m}$, on apothecia of Protoparmeliopsis muralis, on granite outcrops, 20 Oct. 2016, A. Khodosovtsev \& V. Darmostuk (KHER 10321).

Notes. In Ukraine it was known from the Lviv region (Pirogov 2012a). New for the steppe zone of Ukraine.

Tremella phaeophysciae Diederich \& M. S. Christ.

SPECIMEN eXAmined. UKRAINE. Mykolayiv ReGION. Voznesenskiy district, near Trykraty village, Buzky Gard National Nature Park, Labirynt, $47^{\circ} 42^{\prime} 24.9^{\prime \prime} \mathrm{N}$, $31^{\circ} 25^{\prime} 56.9^{\prime \prime} \mathrm{E}$, alt. $42 \mathrm{~m}$, on thalli of Physconia grisea, on Fraxinus excelsior, 21 Oct. 2016, A. Khodosovtsev \& V. Darmostuk (KHER 10310).

Notes. In Ukraine it was known from the Carpathian Mts (Kondratyuk 2012). New for the plains of Ukraine.

Xenonectriella leptaleae (J. Steiner) Rossman \& Lowen

Specimens examined (all on apothecia of Physcia stellaris). UKRAINE. MYKOLAYIV REGION. Voznesenskiy district, near Trykraty village, Buzky Gard National Nature Park, Labirynt, $47^{\circ} 42^{\prime} 24.9^{\prime \prime} \mathrm{N}$, $31^{\circ} 25^{\prime} 56.9^{\prime \prime} \mathrm{E}$, alt. $42 \mathrm{~m}$, on Fraxinus excelsior, 21 Oct. 2016, A. Khodosovtsev \& V. Darmostuk (KHER 10322). SumY REGION. Seredyno-Budskiy district, DesnianskoStarogutsky National Nature Park, near Ochkino village, $52^{\circ} 15^{\prime} 44.1^{\prime \prime} \mathrm{N}, 33^{\circ} 23^{\prime} 21.4^{\prime \prime} \mathrm{E}$, alt. $131 \mathrm{~m}$, on Salix sp., 1 Aug. 2016, A. Khodosovtsev \& V. Darmostuk (KHER 10280).

Notes. In Ukraine it was known from the Lviv region (Pirogov 2012b). New for the steppe zone of Ukraine.

Zwackhiomyces polischukii Darmostuk \& Khodos., sp. nov.

Fig. 1

MycoBAnK MB 820101

Diagnosis. Morphologically similar to the lichenicolous Zwackhiomyces socialis, but differs by its ascospores (17.0-)18.0-21.6(-23.0) $\times$ (5.0-)6.0-7.6(-8.3) $\mu \mathrm{m}$, ascomata $(160-) 170$ 190(-230) $\mu \mathrm{m}$ diam., ascomatal wall ca 15-35 $\mu \mathrm{m}$ wide, and Bacidia hosts.

Type: UKRAINE. Autonomous Republic of Crimea. Livadia, $44^{\circ} 27^{\prime} 50.9^{\prime \prime} \mathrm{N}, 34^{\circ} 08^{\prime} 26.6^{\prime \prime} \mathrm{E}$, alt. $102 \mathrm{~m}$, on Bacidia fraxinea, on Carpinus betulis, 6 May 2006, A. Khodosovtsev \& Yu. Khodosovtseva (ноLОтYPE - KHER 7208, ISOTYPE - KHER 7401).

PaRATyPes (both on thalli of Bacidia rubella). UKRAINE. Autonomous Republic of Crimea. Mount Castel, western slope, $44^{\circ} 43^{\prime} 360.6^{\prime \prime} \mathrm{N}, 34^{\circ} 19^{\prime} 42.8^{\prime \prime} \mathrm{E}$, alt. $110 \mathrm{~m}$, on Carpinus betulis, 15 November 2001, A. Khodosovtsev, S. Zelenko \& O. Bogdan (KHER 2106); Bakhchysarayskiy district, near Manhup-Kale, on Quercus sp., 8 March 1991, A. Khodosovtsev (KHER 10360). KhMELNYTSKIY REGION. KamenetzPodilskiy district, Podilski Yovtry National Nature Park, $48^{\circ} 40^{\prime} 35.2^{\prime \prime} \mathrm{N}, 26^{\circ} 34^{\prime} 28.6^{\prime \prime} \mathrm{E}$, alt. $193 \mathrm{~m}$, on Acer sp., 25 June 2003, O. Bogdan (KHER 7442).

DesCRIPTION. Vegetative hyphae not observed. Ascomata perithecioid, immersed in initial states, semi-immersed at maturity, scattered or in groups of 3-5 pseudothecia, black, subglobose, (160-)170-190(-230) $\mu \mathrm{m}$ diam. $(\mathrm{n}=20)$; ascomatal wall pseudoparenchymatous, dark brown in outer part, brown in middle, and hyaline in inner part; $(15-) 25-30(-35) \mu \mathrm{m}$ wide $(\mathrm{n}=20)$, with 5-8 layers of cells; cells rounded in outer parts and \pm radially compressed in inner part, (4.3-)7.3 $\pm 0.5(-8.8)(\mathrm{n}=25) \mu \mathrm{m}$ wide; granular brown pigments extracellular, turning black or olive-black in K. Hymenial gel I-, K/I-. Paraphysoids abundant, branched and anastomosing, 1.5-2.5 $\mu \mathrm{m}$ thick. Asci clavate, uniseriate to biseriate, (4-)8-spored, $(60-) 65-70(-75) \times(12-) 13.5-15.0(-16) \mu \mathrm{m}$ $(\mathrm{n}=15)$, endoascus I-, BCr-. Ascospores ellipsoid, 1-septate, hyaline, verrucose, markedly constricted at septum, slightly heteropolar, (17.0-) 18.0-21.6(-23.0) × (5.0-)6.0-7.6(-8.3) $\mu \mathrm{m}$, upper cell \pm rounded, lower cell narrower than upper and slightly attenuated, sometimes upper cells with oil droplets; ascospore length/breadth ratio: (1.7-)2.0 $2.7(-3.1)(\mathrm{n}=30)$, halo indistinct, $0.5 \mu \mathrm{m}$ thick in water. Conidiomata not observed.

Host, ECOLOGY AND DISTRIBUTION. The species grows on the thallus of Bacidia fraxinea Lönnr. 


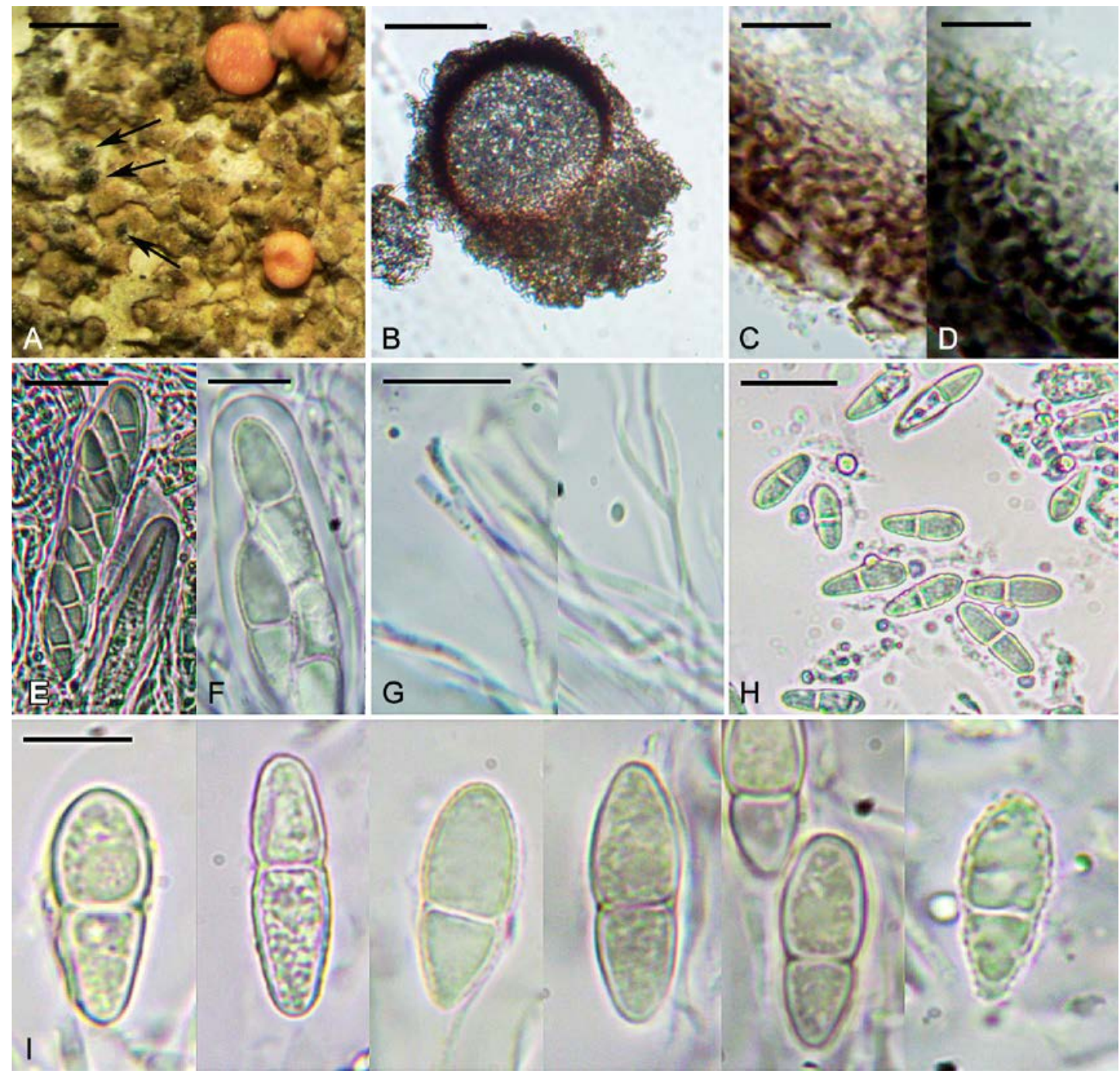

Fig. 1. Morphology of Zwackhiomyces polischukii (all from holotype): A - ascomata (arrows) on thallus of Bacidia fraxinea; $\mathrm{B}$ - section through ascoma; $\mathrm{C}$ - ascomatal wall (in water); $\mathrm{D}$ - ascomatal wall (in $\mathrm{KOH}$ ); $\mathrm{E}$ - asci (in water); $\mathrm{F}$ - ascus (in $\mathrm{KOH}$ ); $\mathrm{G}$ - paraphysoids (in $\mathrm{KOH}$ ); $\mathrm{H}$ - ascospores (in water); $\mathrm{I}$ - ascospores (in water). Scale bars: $\mathrm{A}=500 \mu \mathrm{m} ; \mathrm{B}=100 \mu \mathrm{m}$; $\mathrm{C}, \mathrm{D}$, $\mathrm{F}, \mathrm{I}=10 \mu \mathrm{m} ; \mathrm{E}, \mathrm{G}, \mathrm{H}=20 \mu \mathrm{m}$.

and B. rubella (Hoffm.) A. Massal. on Acer and Carpinus bark. Probably parasymbiotic or weakly parasitic, causing slight deformation of the upper thallus cortex. In one specimen (KHER 2106), apothecia of Bacidia rubella were also infected by Muellerella hospitans Stizenb. The new species is known from four localities in Ukraine.

ETymology. The epithet "polischukii" honors the eminent Ukrainian virologist Professor Valeriy
Polischuk, who actively takes part in our lichenological excursions and discussions.

Notes. Morphologically, Zwackhiomyces polischukii is similar to Z. socialis (Körb.) Cl. Roux (=Z. immersae Arn.) Grube \& Triebel) described from Clauzadea monticola (Ach. ex Schaer.) Hafellner \& Bellem. (original host) and C. metzleri (Körb.) Clauzade \& Roux (Grube \& Hafellner 1990; Roux 2009). Records of Z. socialis from 
terricolous Bacidia baggliettoana (A. Massal. \& De Not.) Jatta (Vouaux 1913) need confirmation. Zwackhiomyces socialis differs from the new species by its smaller ascomata (120-150 $\mu \mathrm{m}$ diam. vs. $160-230$ in Z. polischukii), smaller ascospores $(15.7-18.0 \times 5.0-5.8 \mu \mathrm{m}$ vs. $18.0-21.6$ $\times 6.0-7.6 \mu \mathrm{m}$ in $Z$. polischukii) and thinner perithecial wall (up to $20 \mu \mathrm{m}$ vs. up to $35 \mu \mathrm{m}$ in Z. polischukii). Zwackhiomyces berengerianus (Arnold) Grube \& Triebel has pale brown overmature ascospores (hyaline in Z. polischukii), longer asci (70-95 vs. $60-75$ in $Z$. polischukii), slightly larger ascospores $(17-27 \times 5-10 \mu \mathrm{m}$ vs. $17-23$ $\times 5.0-8.3 \mu \mathrm{m}$ in $Z$. polischukii), and having $M y-$ cobilimbia berengeriana (A. Massal.) Hafellner \& V. Wirth as the host (Grube \& Hafellner 1990). Few Zwackhiomyces species have ascospores similar in size to those of Z. polischukii. Zwackhiomyces dispersus (J. Lahm ex Körb.) Triebel \& Grube differs from $Z$. polischukii by having smaller pyriform ascomata (100-170 $\mu \mathrm{m}$ diam. vs. 160-230 $\mu \mathrm{m}$ diam. in Z. polischukii), and occurs on Protoblastenia rupestris. The recently described Zwackhiomyces solenopsorae van den Boom differs in having smaller ascomata (70-150 $\mu \mathrm{m}$ diam. vs. $160-230 \mu \mathrm{m}$ diam. in $Z$. polischukii), wider asci (17-20 $\mu \mathrm{m}$ wide vs. $12-16 \mu \mathrm{m}$ wide in Z. polischukii), and occurs on the thallus of Solenospora holophaea (Mont.) G. Samp. (van den Boom 2010). Zwackhiomyces turcicus Kocakaya, Halıcı \& A. Aksoy has distinctly larger ascomata (200-450 $\mu \mathrm{m}$ diam. vs. 160-230 $\mu \mathrm{m}$ diam. in Z. polischukii), a wider perithecial wall (30-60 $\mu \mathrm{m}$ wide vs. 15-35 $\mu \mathrm{m}$ wide), mostly 6 -spored asci (8-spored in Z. polischukii), and Physcia as host (Kocakaya et al. 2011).

Acknowledgements. Valeriy Polischuk, Igor Kostikov, Yulia Khodosovtseva, Nataliya Maluga, Anna Naumovich, Vitaly Klymenko, Ivan Moysiyenko, Sergey Panchenko, Volodymyr Bezrukov and Yevgen Kornienko were of indispensable assistance during fieldwork on excursions. We thank Dr. Jan Vondrák for emendations to the manuscript, and Dr. Paul Diederich and the anonymous reviewer for helpful remarks and suggestions on the paper. This study was financially supported by the Ministry of Science and Education of Ukraine (project N 0116U004735).

\section{REFERENCES}

Akulov O. Yu., Dzhagan V. V., Senchilo O. O. \& SukhomLIN M. M. 2010. The first find of Laetisaria fuciformis (McAlpine) Burds. (Corticiaceae) in Ukraine. Ukrayins' $k$. Bot. Zhurn. 67(6): 898-905 (in Ukrainian with English summary).

Alstrup V. 1994. A lichen excursion to Bornholm 1993. Graphis Scripta 6: 49-55.

Alstrup V. \& Cole M. S.1998. Lichenicolous fungi of British Columbia. Bryologist 101: 221-229.

Brackel W. von 2007. Weitere Funde von lichenicolen Pilzen in Bayern. Beitrag zu einer Checkliste III. Ber. Bayer. Bot. Ges. 77: 5-26.

BRACKEL W. vON 2014. Kommentierter Katalog der flechtenbewohnenden Pilze Bayerns. Biblioth. Lichenol. 109: 1-476.

Braun U., Khodosovtsev A. Ye., Darmostuk V. V. \& DieDERICH P. 2016. Trichoconis hafellneri sp. nov. on Xanthoria parietina and Athallia pyracea, a generic discussion of Trichoconis and keys to the species of this genus. Herzogia 29: $307-314$.

Darmostuk V. V. 2016. The genus Cercidospora (Dothideales) in Ukraine. Ukrayins'k. Bot. Zhurn. 73: 262-267 (in Ukrainian with English summary).

Darmostuk V. V. \& Naumovich A. O. 2016. Unguiculariopsis (Helotiaceae, Helotiales), a new genus for the mycobiota of Ukraine. Ukrayins 'k. Bot. Zhurn. 73: 378-381 (in Ukrainian with English summary).

Diederich P., Ertz D. \& Lawrey J. D. 2013. Molecular data place the hyphomycetous lichenicolous genus Sclerococcum close to Dactylospora (Eurotiomycetes) and S. parmeliae in Cladophialophora (Chaetothyriales). Fung. Diversity 58: 61-72.

Diederich P., Lawrey J. D., Sikaroodi M. \& Gillevet P. M. 2011. A new lichenicolous teleomorph is related to plant pathogens in Laetisaria and Limonomyces (Basidiomycota, Corticiales). Mycologia 103: 525-533.

Diederich P., Ertz D., Eichler M., Cezanne R., van den Boom P., Fischer E., Killmann D., van den Broeck D. \& Sérusiaux E. 2012. New or interesting lichens and lichenicolous fungi from Belgium, Luxembourg and northern France. XIV. Bull. Soc. Naturalistes Luxemb. 113: $95-115$.

EsSLINGER T. L. \& EGAN R. S. 1995. A sixth checklist of the lichen-forming, lichenicolous, and allied fungi of the continental United States and Canada. Bryologist 98: 467-549.

Etayo J. 1998. Some hypocrealean lichenicolous fungi from Southwest Europe. Nova Hedwigia 67: 499-510.

Etayo J. \& Diederich P. 1996. Lichenicolous fungi from the western Pyrenees, France and Spain. II. More deuteromycetes. Mycotaxon 60: 415-428.

Etayo J. \& PÉrez-Ortega S. 2016. Lichenicolous lichens 
and fungi from Monfragüe National Park (western Spain). Herzogia 29: 315-328.

Etayo J. \& van den Boom P. P. G. 2006. Some lichenicolous fungi from Guatemala, with the description of a new species. Herzogia 19: 191-197.

Etayo J. \& YAzIci K. 2009. Microsphaeropsis caloplacae sp. nov. on Caloplaca persica in Turkey. Mycotaxon 107: 297-302.

Groner U. 2009. Neue, seltene und interessante Flechten und lichenicole Pilze 4. Meylania 43: 22-23.

Grube M. \& Hafellner J. 1990. Studien an flechtenbewohnenden Pilzen der Sammelgattung Didymella (Ascomycetes, Dothideales). Nova Hedwigia 51: 283-360.

Hafellner J. 1987. Studien über lichenicole Pilze und Flechten VI. Ein verändertes Gattungskonzept für Cercidospora. Herzogia 7: 353-365.

Hafellner J. 1989. Studien über lichenicole Pilze und Flechten. VII: Über die neue Gattung Lichenochora (Ascomycetes, Phyllachorales). Nova Hedwigia 48: 357-370.

HAFELLNER J. 2002. Bemerkenswerte Funde von Flechten und lichenicolen Pilzen auf makaronesischen Inseln VI. Über einige Neufunde. Fritschiana 36: 11-17.

Halici M. G., Hawksworth D. L. \& Aksoy A. 2007. Contributions to the lichenized and lichenicolous fungal biota of Turkey. Mycotaxon 102: 404-414.

Hawksworth D. L. 1981. The lichenicolous coelomycetes. Bull. Brit. Mus. (Nat. Hist.), Bot. 9: 1-198.

HawksworTH D. L. 1992. Nine lichenicolous fungi from Transcarpathians new for Ukraine. Ukrayins'k. Bot. Zhurn. 49: 99-101.

HeiĐmarsson S., Alstrup V., Högnabba F., Motiejūnaité J., Nordin A., Pykälä J., Suija A., Timdal E. \& WestBERG M. 2009. Floristic news from the NLF Iceland excursion 2009. Graphis Scripta 24: 19-25.

Ihlen P. G. \& Wedin M. 2006. Notes on two lichenicolous fungi on Cladonia botrytes in Scandinavia. Graphis Scripta 18: $38-40$.

Joshi Y., Kondratyuk S., LöKös L., Halda J. P., OH S. O. $\&$ Hur J. S. 2015. New species and new records of lichenicolous fungi from South Korea. Mycosphere 6: 493-500.

Joshi Y., Falswal A., Tripathi M., Upadhyay S., Bisht A., Chandra K., BaJPai R., Upreti D. K. 2016. One hundred and five species of lichenicolous biota from India: An updated checklist for the country. Mycosphere 7: 268-294.

KAPETS N. V. 2016. New and rare to Ukraine lichenicolous fungi. Ukrayins'k. Bot. Zhurn. 73: 90-92 (in Ukrainian with English summary).

KeRnStock E. 1896. Lichenologische Beiträge VII. Ehrenburg im Pusterthale. Verh. K.K. Zool.-Bot. Ges. Wien 46: 279-310.

KHodosovtsev A. Ye. 2013. Lichen-forming and lichenicolous fungi from Aju-Dag Mt new to Ukraine and Crimea. Chornomorskiy Botanichchniy Zhurnal 9: 84-88 (in Ukrainian with English summary).

Khodosovtsev A. Ye. \& Darmostuk V. V. 2016. Pleospora xanthoriae sp. nov. (Pleosporaceae, Pleosporales), a new lichenicolous fungus on Xanthoria parietina from Ukraine, with a key to the known lichenicolous species of Dacampia and Pleospora. Opusc. Philolichenum 15: 6-11.

Khodosovtsev A. Ye., Darmostuk V. V., Gromakova A. B. 2016a. New for Ukraine lichen-forming and lichenicolous fungi from Gorgany Nature Reserve. Ukrayins 'k. Bot. Zhurn. 73: 273-276.

Khodosovtsev A. Ye., Gavrylenko L. M. \& Klymenko V. M. 2016b. Katherinomyces cetrariae gen. et sp. nov. (asexual Ascomycota) and Sphaerellothecium aculeatae sp. nov. (Mycosphaerellaceae), new lichenicolous fungi on $\mathrm{Ce}$ traria aculeata in Ukraine. Nova Hedwigia 102: 47-55.

Khodosovtsev A. Ye., Darmostuk V. V., Gromakova A. B. \& SHPILCHAK M. B. 2016c. A first contribution to lichens and lichenicolous fungi of the Nature Reserve «Gorgany» (Ukraine). Chornomorskiy Botanichchniy Zhurnal 12: 51-63 (in Ukrainian with English summary).

Khodosovtsev A., Dymytrova L., Nadyeina A., Naumovych G., Khodosovtseva Yu. \& Scheidegger C. 2013. A contribution to beech forest-associated epiphytic lichenforming and lichenicolous fungi in Crimean Mts (Ukraine). Fl. Medit. 23: 57-68.

Khodosovtsev A., Vondrák J., Naumovich A. KocourKová J., Vondrákova O. \& Motiejūnaité J. 2012. Three new Pronectria species in terricolous and saxicolous microlichen communities (Bionectriaceae, Ascomycota). Nova Hedwigia 95: 211-220.

KocaKaya M., Halici M. G. \& Aksoy A. 2011. Zwackhiomyces turcicus sp. nov. (Ascomycota, Xanthopyreniaceae) from Turkey. Mycotaxon 116: 329-333.

Kocourková J. \& Brackel W. von 2005. Einige für Bayern neue flechtenbewohnende Pilze - Beitrag zu einer Checkliste I. Ber. Bayer. Bot. Ges. Beih. 75: 3-10.

KondratyUK S. YA. 2012. Lichens of main habitats of 'Hutsulshchyna' National Nature Park. Ukrayins 'k. Bot. Zhurn. 69: 397-405 (in Ukrainian with English summary).

Kondratyuk S. Ya., Andrianova T. V. \& Tykhonenko Yu. Yu. 1999. Study of mycobiota diversity of Ukraine ( $\mathrm{Li}$ chenicolous, Septoria and Puccinia fungi): M.G. Kholodny Institute of Botany, Phytosociocentre, Kyiv.

Kondratyuk S. Ya., Popova L. P., Lackovičová A. \& Pišút I. 2003. A catalogue of the Eastern Carpathian lichens. M. H. Kholodny Institute of Botany, National Academy of Sciences of Ukraine \& Institute of Botany, Slovak Academy of Sciences, Kiev - Bratislava.

Kukwa M., Szymczyk R. \& Kowalewska A. 2013. New or interesting records of lichenicolous fungi from Poland IX. Herzogia 26: 159-168. 
MotiejūNaitė J. 2011. Lichens and allied fungi from Kamanos State Strict Nature Reserve (northern Lithuania). Bot. Lithuan. 17: 109-116.

Motiejūnaité J., Chesnokov S. V., Czarnota P., Gagarina L. V., Frolov I., Himelbrant D., Konoreva L. A., Kubiak D., Kukwa M., Moisejevs R., Stepanchikova I., Suija A., Tagirdzhanova G., Thell A. \& Tsurykau A. 2016. Ninety-one species of lichens and allied fungi new to Latvia with a list of additional records from Kurzeme. Herzogia 29: 143-161.

Navarro-Rosinés P., Hafellner J. \& Calatayud V. 2004. Cercidospora. In: H. NASH, B. D. Ryan, P. Diederich, C. Gries \& F. Bungartz (eds.), Lichen Flora of the Greater Sonoran Desert Region. 2: 656-659. Lichens Unlimited, Tempe.

Pirogov M. V. 2010. Clypeococcum hypocenomycis D. Hawksw. - a new species of lichenicolous fungi for Ukraine. Chornomorskiy Botanichchniy Zhurnal 6: 276279 (in Ukrainian with English summary).

Pirogov M. V. 2011. Nectriopsis rubefaciens (Ellis \& Everh.) M.S. Cole \& D. Hawksw. - a new species of lichenicolous fungi for Ukraine. Ukrayins'k. Bot. Zhurn. 68: 127-128 (in Ukrainian with English summary).

Pirogov M. V. 2012a. Lichenicolous fungi of the Ukrainian Roztochya. Visnyk of the Lviv University, Series Biology 59: 73-81 (in Ukrainian with English summary).

PIrogov M. V. 2012b. Two new for mycobiota of Ukraine species of lichenicolous fungi from families Nectriaceae and Bionectriaceae (Hypocreales, Ascomycota). Biologichni Studii 6: 5-19 (in Ukrainian with English summary).

Pirogov M. V. 2015. Clypeococcum cetrariae (Dacampiaceae, Ascomycota) in the Ukrainian Carpathians. Ukrayins' $k$. Bot. Zhurn. 72: 585-587.

Roux C. 2009. Naetrocymbe saxicola, likeno kun Trentepohlia. Bull. Soc. Linn. Provence 60: 127-142.
Triebel D., Rambold G. \& Nash III T. H. 1991. On lichenicolous fungi from continental North America. Mycotaxon 42: 263-296.

WERnER R. G. 1937. Recherches phytogéographiques comparées sur la flore cryptogamique de l'Espagne méridionale et du Maroc. Bull. Soc. Sci. Nat. Maroc 17: 32-66.

VAN DEN Boom P. P. 2010. New or interesting lichens and lichenicolous fungi of Gran Canaria (Canary Islands, Spain). Willdenowia 40: 359-367.

VAN DEN Boom P. P. \& BRAND A. M. 2008. New records of lichens, lichenicolous and allied fungi from Belgium and The Netherlands. Sauteria 15: 95-101.

VAN DEN Boom P. P. \& ETAYo J. 2014. New records of lichenicolous fungi and lichenicolous lichens from the Iberian Peninsula, with the description of four new species and one new genus. Opusc. Philolichenum 13: 44-79.

Vouaux M. 1913. Synopsis des champignons parasites des lichens. Bull. Soc. Mycol. France 29: 33-128, 399-494.

Zhurbenko M. P. 2004. Lichenicolous and some interesting lichenized fungi from the northern Ural, Komi Republic of Russia. Herzogia 17: 77-86.

Zhurbenko M. P. \& Brackel W. V. 2013. Checklist of lichenicolous fungi and lichenicolous lichens of Svalbard, including new species, new records and revisions. Herzogia 26: 323-359.

Zhurbenko M. P. \& SANTESSON R. 1996. Lichenicolous fungi from the Russian Arctic. Herzogia 12: 147-161.

Zhurbenko M. P., Laursen G. A. \& Walker D. A. 2005. New and rare lichenicolous fungi and lichens from the North American Arctic. Mycotaxon 92: 201-212.

Zhurbenko M. P., Frisch A., Ohmura Y. \& Thor G. 2015. Lichenicolous fungi from Japan and Korea: new species, new records and a first synopsis for Japan. Herzogia 28: $762-789$. 